\title{
RESEARCH PAPER \\ SERVICE QUALITY PRACTICES AND STUDENTS SATISFACTION TOWARDS THE DEPARTMENT OF COMMUNICATION DESIGN
}

\author{
A. K. Badu*, E. Appiah and E. F. Eshun \\ Department of Communication Design, College of Built Environment, KNUST, Kumasi \\ "Corresponding author: kbadu70@yahoo.com
}

\begin{abstract}
The increase in the number of tertiary institutions in Ghana offering Communication Design calls for a review of activities in the premium Department of Communication Design in Kwame Nkrumah University of Science and Technology. Grounded in service quality theory, the study examined students' perceptions and satisfaction relationships among five key variables related to satisfaction with service quality: assurance, tangibles, reliability, empathy and responsibility. The design employed for the study was survey. A total of 400 questionnaire were randomly distributed out of which 260 were returned during the end of the second semester of the 2014/2015 academic year. The instrument used for the study was adapted from Cronin and Taylor's Service Quality Questionnaire. The instrument consisted of two parts; Part A consisted of items on respondent's Bio-data while Part B comprised of 22 items which elicited responses from students' perceived satisfaction. The results of the study using the factorial analysis technique indicated that students had negative perceptions and satisfaction about service delivery in the department. The findings suggest that there is a missing link between the department and students. Based on these findings, the researchers recommend that there should be an avenue where students can address their concerns without malice, and also ensure that these concerns are given the maximum consideration.
\end{abstract}

Keywords: Service quality, SERVPERF, higher education, students' perceptions

\section{INTRODUCTION}

Tertiary or higher level education is acknowledged universally as one of the necessary conditions for attaining personal achievement, social development and cohesion in any society. Societal goals in development, economics, poli- tics and consistent interrelations between people become highly attainable when members of the society are highly educated. In the work of Coates (2005), it was stated that students, faculty, administrators, financial support and physical facilities were described as inputs to 


\section{Badu et al.}

the education system; whereas educated people, research findings and service to the community were the outputs/products of the education system.

Interest in the quality of university education has grown considerably over the last decade. Students need accurate information about educational quality to help them choose between different courses of study. Academics and university administrators need information to help them monitor and improve their courses and programmes. Institutions need information about quality to help them benchmark and market their performance. Governments and other bodies need information to assist with funding, policy development and accountability. For these and many more reasons, quality assurance has become vital in the higher education system (Coates, 2005).But, in today's competitive environment as quoted by Al-Alak and Alnaser (2012), it is becoming more difficult for universities to enhance and maintain a competitive advantage in their own target markets. Markovic (2005), suggested that factors that enable educational institutions to attract and retain students should be studied seriously as many options are open to them. It is, therefore, vital for higher education institutions to actively monitor the quality of services and safeguard the interests of stakeholders through the fulfillment of their real needs and wants (Zeshan, 2010; Al-alak, 2009).

At the heart of service delivery according to Oldfield and Baron (2000) lies the interaction between customers and service organizations. Employees, who deliver the service, in this case the instructors, are of key importance to both the customers they serve, that is the students, and the employer they represent, that is the university. In some regards, the employee (instructor) may be the most visible route by which the employer (the university) can distinguish itself (Stodnick and Rogers, 2008). Better measures of the customers' voices through their assessment of service quality may ultimately lead to improved educational experience (student), increased professional development of faculty, higher university ranking and betterqualified graduates.

Recently, there has been an increase in the number of private universities to complement the ten public universities in Ghana. As private participation is increasing, competition between the public and private tertiary institution is also increasing. These private institutions are offering similar courses as offered by the public tertiary institutions. Can the academic departments in the public universities rely on the brand name of their institutions to operate or lift up the game to distinguish themselves to be ahead of their competitors? Are students satisfied with services rendered to them? The purpose of this research was to measure service quality at the department level and to determine the level of satisfaction amongst students. Students, professional bodies, and governments who are the stakeholders in higher education have their own view of quality due to particular needs. Therefore, this paper considers students perception and does not suggest that other perspectives are not valid and important.

\section{Service quality}

Service quality has since the 1980's emerged as a pervasive strategic force and a key strategic issue on management's agenda. It is no surprise that practitioners and academics alike are keen on accurately measuring service quality in order to better understand its essential antecedents and consequences, and ultimately, establish methods for improving quality to achieve competitive advantage and build customer loyalty (Abdullah, 2005). The common themes that run through numerous definitions of service are intangibility and simultaneous consumption (Fitzsimmons and Fitzsimmons, 2001). According to Zerher (2009) there are four characteristics of service that make it different from goods and these are;

(1) Intangibles - Services are acts and functions, but are not physically present as tangible objects. 
(2) Perishability - A service cannot be stored for later use.

(3) Heterogeneity - Services are created individually for each customer, and service scope and quality can differ in accordance with the behaviour, knowledge, and servicemindedness of the service provider's employees and the consumers.

(4) Simultaneous occurrence - Services are characterised by the coincidence of production and consumption because the service is usually created in contact with the consumer.

\section{Service quality and student satisfaction}

According to Jain et al. (2010) there is considerable debate about the best way to define service quality in Higher Education. In the research by Akbar and Pervez (2009) customer satisfaction was said to be a well-known and established concept in several areas like marketing, consumer research, economic psychology, welfare-economics and economics. The most common interpretations obtained from various authors reflect the notion that satisfaction is a feeling which results from a process of evaluating what has been received against what was expected, including the purchase decision itself and the needs and wants associated with the purchase. Bitner and Zeithaml (2003) stated that satisfaction is the customers' evaluation of a product or service in terms of whether that product or service has met their needs and expectations. The expectation may go as far as before the students even enter the higher education (Palacio et al, 2002).

On the contrary, Carey et al., (2002), believe that satisfaction actually covers issues of students' perception and experiences during the college years. Thus institutions and teachers need to provide students with the appropriate resources and opportunities to promote specific kinds of interactions. This may involve academic staff making themselves available for consultation outside class time, campus librar- ies having sufficient space for students to work collaboratively, curricula and assessment that compel certain standards of performance or activities and events around campus that prompt students to reflect on the ethics and practices of their learning (Coates, 2005). This according to Yeo (2008), does not happen overnight. It requires a persistent endurance to withstand the test of time through collective mindsets and efforts. Success depends on the dynamic exchange of mental models of both academic and non-academic staff in achieving service quality. Although, such individual attributes as attitude and motivation may be difficult to modify over a short period, given the right stimulus through, for instance, an appropriate reward and compensation system, mental models can be changed for the benefit of the institution. Thus, a proper understanding of the antecedents and determinants of customer satisfaction can be seen as having an extraordinarily high monetary value for service organizations in a competitive environment (Lassar et al 2000).

\section{Theoretical models for service quality}

According to Yeo (2008), in a world where branding becomes the basis for competition of unique products and services in attracting a larger market share for ultimate profitability, consumers are largely spoilt with choice. How does one decide which product or service is better than others? While a multitude of factors may contribute to the decision process, one underlying factor that differentiates itself and taps into the direct experience of the consumer is "service quality", (Cronin and Taylor, 1992).

Since the 1980s service quality has been linked with increased profitability, and it is seen as providing an important competitive advantage by generating repeat sales, positive word-ofmouth feedback, customer loyalty and competitive product differentiation. A survey of the service marketing literature reveals two main approaches to measure service quality:

SERVQUAL (Parasuraman et al., 1988) and SERVPERF (Cronin and Taylor, 1992). 


\section{Badu et al.}

SERVQUAL has its theoretical foundations in the gaps model and defines service quality in terms of the difference between customer expectations and performance perceptions. Customer expectations are "beliefs about service delivery that serve as standards or reference points against which performance is judged", whereas customer perceptions are "subjective assessments of actual services experiments" through interaction with the providers (Zeithaml and Bitner, 2006). Parasuraman et al. (1988), developed the SERVQUAL model (Fig. 1) which is a multi-item scale developed to assess customer perceptions of service quality in service and retail businesses. The scale decomposes the notion of service quality into five constructs: Tangibles, Reliability, Responsiveness, Assurance and Empathy. These constructs are further elaborated as:

- Tangibles - refers to the appearance of physical facilities, equipment, personnel and communication materials.

- Reliability - refers to the ability to perform the promised service dependably and accurately.

- Responsiveness - refers to the willingness to help customers and to provide prompt service.
- Assurance - refers to the knowledge, courtesy of employees and ability to convey trust and confidence in the customer towards the service provider.

- Empathy - refers to the provision of caring, individualized attention provided to customers.

It is based on capturing the gap between customers' expectations and experience which could be negative or positive if the expectation is higher than experience or expectation is less than or equal to experience respectively (Chingang and Lukong, 2010). In the context of higher education according to Zeithaml and Bitner (2006), these dimensions include the appearance of the university's physical facilities, equipment, personnel, and communication materials (tangibles, measured by four items), the ability of the university to perform the promised service dependably and accurately (reliability, measured by five items), the willingness of the university to help students and provide prompt service (responsiveness, four items) the knowledge and courtesy of teachers and their ability to convey trust and confidence (assurance, four items) and the caring, individualized attention the university provides its students with (empathy, five items).

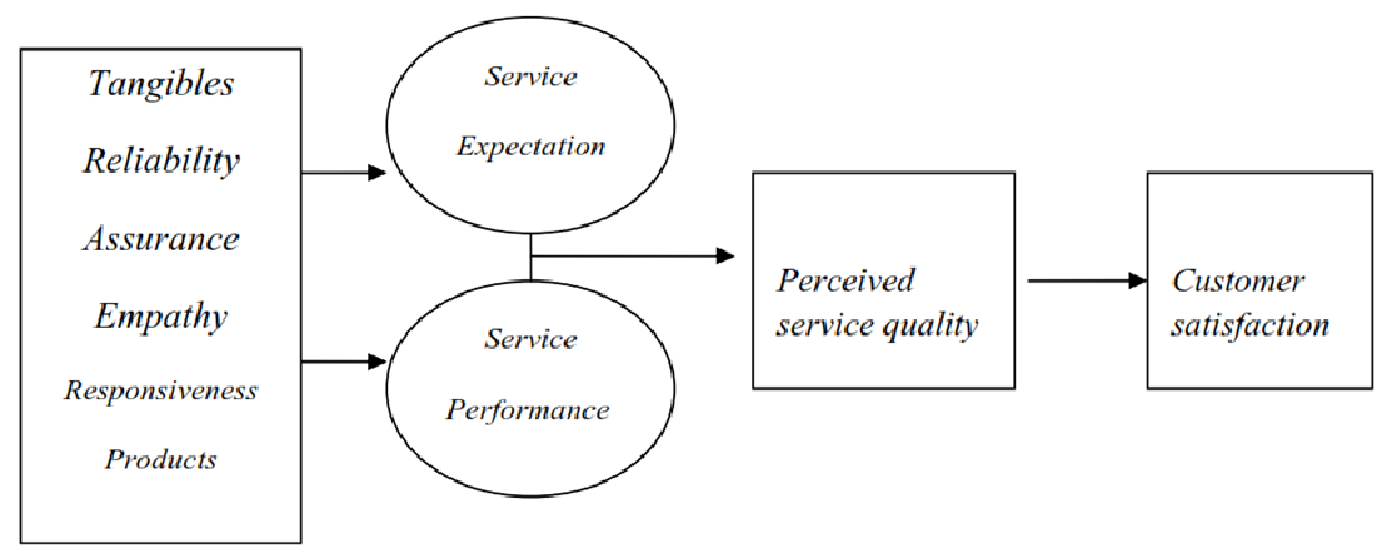

Fig. 1 SERVQUAL Model (Source: Kuma et al, 2009) 
Due to the controversy relating to the SERVQUAL instrument, a more direct approach to the measurement of service quality has been proposed. The new approach was developed as the measurement instrument called SERVPERF which is used for the service quality assessment. The SERVPERF instrument like the SERVQUAL uses an attribute approach. But in comparison with SERVQUAL the SERVPERF tool measures only customers' experiences of the service. This instrument makes use of the original SERVQUAL scales.

Comparing with SERVQUAL,SERVPERF uses a single set of questions concerning post consumption perceptions of service quality and does not seek to measure expectations. It was illustrated that service quality is a form of consumer attitude. Therefore, measuring only performance of service quality is an enhanced means of measuring service quality (Shauchenka and Buslowski, 2010). According to Scott and Brian(1996), SERVPERF boils down to a simple equation:

Service Quality = Performance

\section{RESEARCH METHODOLOGY}

The study does not seek to generalize its findings as it is in its preliminary stage of finding a wider perception of student satisfaction with the university. It is a quantitative study involving the administration of questionnaire which is based on SERVPERF (Cronin and Taylor, 1992). The sampling frame was the four different year groups from the Department of Communication Design, totaling about 600. A total of 400 questionnaire were randomly distributed to students out of which 260 were returned during the end of second semester of the 2014/2015 academic year, of which males and females had equal representation. Factor analysis was used in analyzing the responds in this study. Each student was asked to voluntarily fill out the survey at the end a lecture. There were two sections in the questionnaire, section $\mathrm{A}$ consisted of demographic factors covering the subjects of gender, age, and their year of study, section B covered measurement of service quality in higher education using SERVPERV which is based on SERVQUAL dimensions. The questions used on the survey were derived from a study by Shauchenka and Busłowska (2010). The respondents were supposed to rate 22 statements on a five point-Likert scale which ranged from 1 to 5 . While 1 represents "strongly agree" which denotes a very strong positive perception, 5 represents "strongly disagree" which denotes a very strong negative perception. Neutrality is denoted by 3 . Since 3, represents the point of neutrality, average means from 1.0 to 2.9 denote a decreasing positive perception while those from 3.1 to 5.0 denote an increasing negative perception.

\section{RESULTS}

Factor analysis was used in analyzing the data. The 22 components (variables) of the questionnaire were loaded into the SPSS software . Cronbach's Alpha stood at .87 indicating a very robust analysis. Secondly, it has to be established if the factor analysis carried out would yield distinct and reliable factors. This information is displayed in the Table 1. The Kaiser-

Table 1: Kaiser-Meyer-Olkin and Bartlett's Test

\begin{tabular}{lll}
\hline Kaiser-Meyer-Olkin measure of sampling adequacy & & .874 \\
\hline Bartlett's Test of Sphericity & Approx. Chi-Square & 1539.454 \\
& Df & 153 \\
& Sig. & .000 \\
\hline
\end{tabular}




\section{Badu et al.}

Meyer-Olkin and Bartlett's Test figure would determine if the analysis would yield distinct and reliable factors. A value near or equal to 0 would mean factor analysis would not yield distinct and reliable factors while a value close to or equal to 1 means the analysis would do as required. Values between 0.5 and 0.7 are considered mediocre, those between 0.7 and 0.8 are good, and those between 0.8 and 0.9 are great while those above 0.9 are excellent. Since the value from the analysis is 0.874 , it is clear that the factor analysis would yield distinct and reliable factors.

For factor analysis to work, it has to be established that there is a relationship between the variables. This is determined by the Bartlett's Test of Sphericity. If the significance value of this test is less than or equal to 0.05 , then it shows there is a significant relationship between the variables. Looking at Table 1, the significance value is 0.000 , showing that there is a significant relationship between the variables.

\section{Reliability}

The variables that make up this factor seek to measure whether the students perceive their lecturers and other staff as reliable people; whether the lecturers and other staff are sincere and whether they persist in their sincerity. This factor is made up of variables with high factor loadings such as "when a student has a problem the department demonstrates sincere interest in solving it" (loading: 0.771), "when a promise is made to do something at a certain time, it does so" (loading: 0.771), "the department does the job right the first time and persists in doing it without error" (loading: 0.689), "the department readily responds to student's queries at all times" (loading: 0.632). These can be found in Table 2 .

The factor also has a very good reliability coefficient: .760. Looking at the averages displayed in Table 3, it is obvious both males and females have a similar perception of the reliability of the faculty and other staff of the department.
Students are undecided, this is because, their average means are approximately 3.0 (which indicates "undecided" on the questionnaire). This might be due to a situation of not being satisfied with what they are getting as far as this dimension is concerned but do not want to hurt the feelings of their staff by stating that.

\section{Tangibles}

Variables which seek to measure the students' perception of the facilities provided by the department form this factor. They measure features such as appropriate equipment, wellfurnished and well-lit classrooms, computer labs, studios and others. The factor is dominated by variables such as: "the department has modern equipment such as computer lab, design studio, photo lab etc." (loading: 0.728), "material associated with the service such as journals, printed matter, have good visual appearance and be up to date" (loading: 0.706) and "the department has modern architecture with spacious, well lighted and ventilated lecture rooms with ample furniture" (loading: 0.662). As indicated in table 2 above, the factor also has quite a good reliability coefficient: .673.Generally, the students have a negative perception of the facilities of the department. The results displayed in Table 4 shows that the students somehow had a bad perception of this dimension. While the items on the questionnaire try to suggest to them that everything is perfect, they seem to think otherwise. This is because they have crossed the "undecided" line and are heading towards "disagree" which is denoted by 4 on the questionnaire. That situation can be interpreted to mean that students held a weak negative perception about the facilities of the department. This is not surprising taking into account the kind of facilities in the department: classrooms built out of plywood, most of them, poorly ventilated, no wellstocked computer labs, poor internet facilities and others.

\section{Responsibility}

The next factor is made up of variables which seek to measure how diligently employees of 
Table 2: Rotated component matrix

\begin{tabular}{|c|c|c|c|c|c|}
\hline & \multicolumn{2}{|c|}{ Component } & \multirow[b]{2}{*}{3} & \multirow[b]{2}{*}{4} & \multirow[b]{2}{*}{5} \\
\hline & 1 & 2 & & & \\
\hline $\begin{array}{l}\text { When a student has a problem the department demonstrates } \\
\text { sincere interest in solving it. }\end{array}$ & .771 & & & & \\
\hline $\begin{array}{l}\text { When a promise is made to do something at a certain time the } \\
\text { department does so. }\end{array}$ & .771 & & & & \\
\hline $\begin{array}{l}\text { The department does the job right the first time and persists in } \\
\text { doing it without error. }\end{array}$ & 689 & & & & \\
\hline The department readily responds to student's queries at all times. & 632 & & & & \\
\hline Students relate comfortably with lecturers and employee. & & .762 & & & \\
\hline The department understands the specific needs of their students. & & 600 & .471 & & \\
\hline $\begin{array}{l}\text { The behaviour of employees and lecturers inspire confidence in } \\
\text { the students. }\end{array}$ & & .583 & & .440 & \\
\hline The department is focused on the best service for their students. & & .554 & .442 & & \\
\hline $\begin{array}{l}\text { Students have confidence in the course outline and the teaching } \\
\text { methods. }\end{array}$ & & & .721 & & \\
\hline The department has convenient business hours for all students. & & & 642 & & \\
\hline $\begin{array}{l}\text { The department has employees and lecturers who provide } \\
\text { individual attention to each student. }\end{array}$ & & .400 & 612 & & \\
\hline $\begin{array}{l}\text { Employees and lecturers have the knowledge needed to answer } \\
\text { students' questions. }\end{array}$ & & & .442 & .439 & \\
\hline $\begin{array}{l}\text { Employees and lecturers promise students the service within } \\
\text { deadlines and are able to meet it. }\end{array}$ & & & & 684 & \\
\hline $\begin{array}{l}\text { Employees and lecturers are always explaining doubts their } \\
\text { students may have. }\end{array}$ & & .451 & & 620 & \\
\hline Students feel safe in their transactions with the department. & & .424 & & .542 & \\
\hline $\begin{array}{l}\text { The department has modern architecture with spacious, well } \\
\text { lighted and ventilated lecture rooms with ample furniture. }\end{array}$ & & & & & .728 \\
\hline $\begin{array}{l}\text { Material associated with the service such as journals, printed } \\
\text { matter, have good visual appearance and be up to date. }\end{array}$ & & .410 & & & .706 \\
\hline $\begin{array}{l}\text { The department has modern equipment such as computer lab, } \\
\text { design studio, photo lab etc. }\end{array}$ & & & & & .662 \\
\hline
\end{tabular}

Table 3: Students' perception about service reliability

\begin{tabular}{lll}
\hline Gender & Mean & N \\
\hline Male & 2.9523 & 131 \\
Female & 3.0407 & 129 \\
Total & $\mathbf{2 . 9 9 6 2}$ & $\mathbf{2 6 0}$ \\
\hline
\end{tabular}

Table 4: Students' perception about tangibles

\begin{tabular}{lll}
\hline Gender & Mean & N \\
\hline Male & 3.2443 & 131 \\
Female & 3.3612 & 129 \\
Total & $\mathbf{3 . 3 0 2 3}$ & $\mathbf{2 6 0}$ \\
\hline
\end{tabular}




\section{Badu et al.}

the department perform their duties. The factor is dominated by variables such as "employees and lecturers promise students the service within deadlines and are able to meet them" (loading: 0.684) and "employees and lecturers are always explaining doubts their students may have" (loading: 0.620). The factor also has a reliability coefficient of .738 .

Generally, the students hold a weak positive perception of the responsibility of the staff of the department. The results, as shown in Table 5 indicates that gender-wise, the respondents hold a weak positive perception of the staff of the department. With averages just above 2 (which indicates "agree" on the questionnaire), it can be concluded that they have a bit of a positive perception regarding the responsibility of the staff. With an average of approximately 2.5 , the males, however, seem to have more positive perceptions of the responsibility of the staff than the females.

The results from the Table 6 suggests that the second year students have a more positive perception of the responsibility of their lecturers. Their mean of approximately 2.3 shows clearly that they have a positive perception. The fourth year students, with a mean of 2.8 have the least positive perception of the responsibility of their lecturers.

\section{Assurance}

The four variables which form this factor seek to find out if the students have confidence in the capability of their lecturers and other staff. In other words, whether the students feel safe in their dealings with the staff and whether they believe the staffs have the needed knowledge to help them give the students a good education. The factor is dominated by variables such as "students have confidence in the course outline and the teaching methods" (loading: .721) and "employees and lecturers have the knowledge needed to answer students' questions" (loading: .442 ). The factor also has quite a robust Cronbach's alpha: 697 .

Looking through the figures in Table 7, it is clear the second year students are the ones with a more positive perception of the capability of the staff followed by the first year students. The third and final year students, held a weak positive perceptions of the capabilities of staff. This

Table 5: Responsibility by gender of respondents

\begin{tabular}{lll}
\hline Gender & Mean & No. \\
\hline Male & 2.5439 & 131 \\
Female & 2.7093 & 129 \\
Total & $\mathbf{2 . 6 2 6 0}$ & $\mathbf{2 6 0}$ \\
\hline
\end{tabular}

Table 6: Responsibility according to respondents' academic level

\begin{tabular}{lll}
\hline Respondents' academic level & Mean & N \\
\hline 100 & 2.5240 & 73 \\
200 & 2.2838 & 37 \\
300 & 2.6949 & 59 \\
400 & 2.8022 & 91 \\
Total & $\mathbf{2 . 6 2 6 0}$ & $\mathbf{2 6 0}$ \\
\hline
\end{tabular}


might be as a result of the fact that they have had to deal with the staff for a longer time than the first and second year groups.

\section{Empathy}

This factor is made up of variables that measure how the students relate with the staff of the department. This include whether the students are able to enjoy situations such as the opportunity to get individual attention from the staff, whether their individual specific needs are usually taken care of, and whether the staff provides the best possible services for the students. The factor is made up of variables such as "students relate comfortably with lecturers and employee" (loading: 0.762), "the department understands the specific needs of their students" (loading: 0.600), and "the department has employees and lecturers who provide individual attention to each student" (loading: 0.400 ). These can be found in Table 2. With a reliability coefficient of .798 , the factor has proven to be very reliable.

With a general mean of approximately 2.9 , it is safe to conclude that the students have a very weak positive perception of this dimension of the survey instrument. There is really no significant difference between the perception of males and that of females: they both have a

Table 7: Respondents' perceptions of assurance

\begin{tabular}{lll}
\hline Respondents' academic level & Mean & No. \\
\hline 100 & 2.6027 & 73 \\
200 & 2.3446 & 37 \\
300 & 2.8432 & 59 \\
400 & 2.8297 & 91 \\
Total & $\mathbf{2 . 7 0 0 0}$ & $\mathbf{2 6 0}$ \\
\hline
\end{tabular}

Table 8: Respondents' perception of empathy

\begin{tabular}{lll}
\hline Gender & Mean & No. \\
\hline Male & 2.8382 & 131 \\
Female & 2.9039 & 129 \\
Total & $\mathbf{2 . 8 7 0 8}$ & $\mathbf{2 6 0}$ \\
\hline
\end{tabular}

Table 9: Empathy: respondents' academic level

\begin{tabular}{lll}
\hline Respondents' academic level & Mean & No. \\
\hline 100 & 2.7315 & 73 \\
200 & 2.4595 & 37 \\
300 & 2.0881 & 59 \\
400 & 2.0088 & 91 \\
Total & $\mathbf{2 . 8 7 0 8}$ & $\mathbf{2 6 0}$ \\
\hline
\end{tabular}




\section{Badu et al.}

very weak positive perception of this dimension of the questionnaire. This is shown by their respective averages of 2.8 and 2.9 in Table 8.

The two senior years groups completely remained undecided as far as the relationship between the students and the staff is concerned; they both have a mean of approximately 3.0 (which indicates "undecided" on the survey instrument). The two junior year groups however hold a weak positive perception about the relationship between the students and the staff, with the second years holding the more positive perception as can be seen in the Table 9 .

\section{Overall average}

Overall, this study found out that the students have an extremely weak positive perception of service quality delivery in the department designated for this study. With an overall mean of approximately 2.9 , it is safe to draw the above conclusion as indicated in Table 10.

To find out if there is a significant difference between the perceptions they hold, an Analysis of variance (ANOVA) test conducted returned results shown in Table 11.
Looking at the significance value in Table 10 based on gender, it is clear that the perception of the males is not any different from that of the females as far as service quality in the department is concerned. A significance value of .196 is way higher than the 0.05 used as the significance level during the analysis. For there to be a significant difference between their perceptions, the significance value (denoted by "Sig." in Table 11) has to be less or equal to 0.05 after the ANOVA test is conducted.

The perception of the respondents based on academic levels does not seem any different. Generally the respondents still hold a very weak perception of service quality in the department. This is evident in the means returned by the test as shown in Table 12 .

However, it is obvious there is a significant difference between the levels of their perceptions. While the third and fourth year students show clearly their indecision, the second year students hold a weak positive perception about service quality in the department. Table 13 detailed the results of an ANOVA test.

Table 10: Overall average of students' perception of service delivery

\begin{tabular}{lll}
\hline Gender & Mean & No. \\
\hline Male & 2.8520 & 131 \\
Female & 2.9468 & 129 \\
Total & $\mathbf{2 . 8 9 9 0}$ & $\mathbf{2 6 0}$ \\
\hline
\end{tabular}

Table 11: ANOVA test conducted

\begin{tabular}{lccccc}
\hline & Sum of squares & df & Mean square & F & Sig. \\
\hline Between groups & .585 & 1 & .585 & 1.680 & .196 \\
Within groups & 89.797 & 258 & .348 & & \\
Total & $\mathbf{9 0 . 3 8 1}$ & $\mathbf{2 5 9}$ & & & \\
\hline
\end{tabular}


Table 12: Overall average of students' (academic level) perception of service delivery

\begin{tabular}{lll}
\hline Respondents' academic level & Mean & No. \\
\hline 100 & 2.7899 & 73 \\
200 & 2.6592 & 37 \\
300 & 2.0364 & 59 \\
400 & 2.9951 & 91 \\
Total & $\mathbf{2 . 8 9 9 0}$ & $\mathbf{2 6 0}$ \\
\hline
\end{tabular}

Table 13: ANOVA test conducted

\begin{tabular}{llllll}
\hline & Sum of squares & df & Mean square & F & Sig. \\
\hline Between groups & 4.951 & 3 & 1.650 & 4.946 & .002 \\
Within groups & 85.430 & 256 & .334 & & \\
Total & $\mathbf{9 0 . 3 8 1}$ & $\mathbf{2 5 9}$ & & & \\
\hline
\end{tabular}

Table 13 backs the claim that there is a statistically significant difference between their perceptions. The significance value, which has to be less or equal to .05 for one to conclude that there is a significant difference between their perceptions, is really very low in this case: .002 .

\section{RECOMMENDATIONAND CONCLU- SION}

The results show that the service quality dimensions (tangibles, responsiveness, reliability, assurance and empathy) have strong relationship with students' satisfaction. Not a single one of the five service dimensions looked favourable to the students. At every stage of service encounter at the department, there is disappointment or service failure which comes with grave consequences. The researchers are of the view that there should be an avenue where students can address their concerns without malice, and also ensure that these concerns are given the maximum consideration. As students play a significant role in the service delivery process as clearly characterized in simultaneous production and consumption, training for staff must be encouraged and there must be swift information flow regarding activities of the department to avoid dissatisfaction. At any point in time, personnel should show keen interest in the activities in the department and be abreast with current issues relating to service delivery. Most importantly, academic facilities such as lecture rooms, furniture and laboratories must be provided or upgraded.

Again, staff, especially teaching staff must show professionalism in their appearance. The department has moved into a new building with state-of-the-art lecture rooms. With the exception of the graduating class all respondents would be available to find out if there would be significant improvement in their responses to service delivery. Other departments in the Kwame Nkrumah University of Science and Technology could take an introspective view of students' perception about their service delivery for them to identify any lapses and work assiduously to improve them. 
In conclusion, service delivery at the Department of Communication Design does not appeal to the students. It also means many have graduated without satisfaction. For fear of victimization their grievances lie silently within them and they leave the university without satisfaction. It suggests that the department is operating on a time bomb and if conscious effort is not taken to improve on performance, by word-of-mouth (Zeithaml and Bitner., 2006), they silently spread the bad news about the service delivery of the department to dent the image of the university as a whole.

\section{REFERENCES}

Abdullah, F. (2006). Measuring service quality in higher education: HEdPERF versus SERVPERF. Marketing Intelligence and Planning, 24 (1): 31- 47.

Akbar, M. M. and Parvez, N. (2009). Can service quality, trust, and customer Satisfaction engender customers loyalty? ABAC Journal, 29 (1): $24-38$

Al-Alak, B. A. and Alnaser, A. S. M. (2012). Assessing the relationship between higher education service quality dimensions and student satisfaction. Australian Journal of Basic and Applied Sciences, 6(1): 156-164.

Al-alak, B. A. (2009). Measuring and evaluating business students' satisfaction perceptions at Public and Private Universities in Jordan. Asian Journal of Marketing, 3 (2): 33-51

Bitner, M. J. and Zeithaml, V. A. (2003). Service Marketing (3ed.), Tata McGraw Hill, New Delhi.

Carey, K., Cambiano, R. L. and De Vore, J. B. (2002). Student to faculty satisfaction at a Midwestern university in the United States. HERDSA, 93-97. Retrieved August $28^{\text {th }} 2004$, fromwww.ecu.edu.au/conferences/ herdsa/main/papers/ref/pdf/ Carey.pdf
Chingang, N. D. and Lukong P. B. (2010). Using the SERVQUAL Model to assess Service Quality and Customer Satisfaction. An Empirical study of grocery stores in Umea. Umea School of Business, Master thesis, Umea University.

Coates, H. (2005). The value of Student Engagement for Higher Education BL Quality Assurance. Quality in Higher Education, 11 (1): 25-36.

Cronin, J. J. and Taylor S. A. (1992). Measuring Service Quality: re-examination and extension. Journal of Marketing Research, 56 (2): 55-68.

Fitzsimmons, J. A. and Fitzsimmons, M. J. (2001). Service Management: Operations Strategy and Information Technology, 3rd edition, Singapore: McGraw-Hill Inc.

Jain,. R., Sinha, G. and DeS, .K. (2010). Service quality in higher education: An exploratory study. Asian Journal of Marketing, 4(3): 144-154.

Kumar, M., Kee, F. T. and Manshor, A. T. (2009). Determining the relative importance of critical factors in delivering service quality of banks; An application of dominance analysis SERVQUAL model. Managing Service Quality, 19(2): 211-228

Lasser, W. M., Manolis, C. and Winsor, R. D. (2000). Service quality perspectives and satisfaction in private banking. Journal of Marketing, 14(3): 244-271.

Markovic, S. (2005). Student's Expectations and Perceptions in Croatian Tourism and Hospitality Higher Education: SERVQUAL versus UNIQUAL. South East European Journal of Economics and Business, 1(2):7896

Oldfield, B. M. and Baron, S. (2000). Students' perception of service quality in a UK Univ- 
ersity business and management faculty. Quality Assurance in Education. 8(2): 85-95.

Palacio, A. B., Meneses, G. D. and Perez, P. J. P. (2002). The configuration of the university image and its relationship with the satisfaction of students. Journal of Educational Administration, 40 (5): 486-505.

Parasuraman, A., Zeithaml, V., and Berry, L. (1988). SERVQUAL: a multiple item scale for measuring consumer perceptions of service quality. Journal of Retailing, 6(1): 1236.

Scott, C. B. and Brain H. (1996). How to measure customer service effectively. Managing Service Quality: An International Journal, 6 (1): 36-39

Shauchenka, H. and Buslowski, E. (2010). Methods and tools for higher education Service quality assessment (survey). ZeszytyNaukowe Politechniki Bialostockiej. Informatyka, 5: 87 - 102 .

Stodnick, M. and Rogers, P. (2008). Using
SERVQUAL to measure the quality of the classroom experience. Decision Sciences Journal of Innovative Education, 6(1): 115133

Yeo, R. K. (2008). Service quality in higher education: quest for excellence. On the Horizon, 16(3): 152-161.

Zehrer, A. (2009). Service experience and service design: concepts and application in tourism SMEs. Managing Service Quality: An International Journal, 19(3): 332-349.

Zeithaml, V. A. and Bitner, M. J. (2006). Service Marketing: Integrating Customer Focus Across the Firm $4{ }^{\text {th }}$ Edn, McGraw Hill, NY.

Zeshan, M., Afridi, T. A. H. I. R. A. and Khan, S. M. (2014). Assessing service quality in business schools: Implications for improvement. IMPACT. International Journal of Research in Applied, Natural and Social Sciences, 2 (8) 33-42. 